\title{
The impact of various factors related to the COVID-19 pandemic on the mental health of healthcare workers in the Republic of North Macedonia
}

\author{
Sanja Filkova ${ }^{2 *}$, Branka Pashaliska Cvetkov ${ }^{2}$, Vasko Aleksovski ${ }^{2}$, \\ Olivera Krstic Nakovska ${ }^{3}$, Dimitar Karkinski ${ }^{3}$, Irina Angjelovska ${ }^{3}$, \\ Angjela Debreshliovska ${ }^{3}$

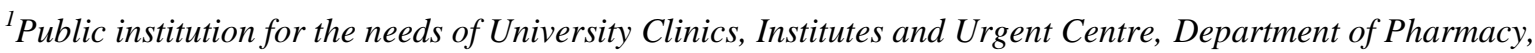 \\ Majka Tereza 17, 1000 Skopje, Republic of North Macedonia \\ ${ }^{2}$ University Clinic of Neurology, Majka Tereza 17, 1000 Skopje, Republic of North Macedonia \\ ${ }^{3}$ University Clinic of Pulmology and Allergology, Majka Tereza 17, \\ 1000 Skopje, Republic of North Macedonia
}

Received: May 2021; Accepted: June 2021

\begin{abstract}
Since December 2019, the world has been facing an unprecedented infection caused by a new strain of coronavirus called SARSCoV-2. The COVID-19 pandemic, in addition to affecting every aspect of daily life, further affects the already high levels of stress, anxiety and depression faced by healthcare workers (HCWs) globally. Protecting the mental health of HCWs should be recognized as an imperative during a pandemic.

This paper aims to examine, by means of an anonymous survey, the attitudes and opinions of HCWs regarding the COVID-19 pandemic, as well as their mental health condition and the causes of mental disabilities. The survey encompassed HCWs (doctors, nurses/technicians and pharmacists) engaged in COVID-19 centers at the University Clinical Center „Majka Tereza“, Skopje.

The results of the conducted research indicate that during the engagement in the COVID-19 centers, the HCWs faced the burnout syndrome, fear of infecting primarily family members, colleagues or negative patients, isolation etc. Most of the participants never sought psychological help, sometimes thought about how they could no longer endure the situation, and often experienced problems sleeping, but they didn't use sleeping or calming pills. Almost half of the participants felt that they were not adequately protected in the workplace. The negative consequences of mental health are more pronounced in HCWs who are directly engaged in the treatment of patients with COVID-19.

This research contributes to a better understanding of the mental health of HCWs and the need for interventions by the system in the form of education and care.
\end{abstract}

Keywords: COVID-19, healthcare workers, risks, measures, mental health

\section{Introduction}

In December, 2019, Wuhan, Hubei province, China, became the center of an outbreak of pneumonia of an unknown cause, which drew great attention not only within China but internationally (Wang et al., 2020). Later, on March 11, 2020, the World Health Organization (WHO) held a virtual press conference on coronavirus disease 2019 (COVID-19) and declared the global

\footnotetext{
*s_filkova@hotmail.com
} 
COVID-19 pandemic (WHO, 2020). The number of sick and dead is rising daily. Globally, by February 22, 2021, there have been 111.100.016 confirmed cases of COVID19, including 2.462.911 deaths (WHO, 2021). Worldometer reports 99.408 Coronavirus cases and 3.076 deaths in the Republic of North Macedonia (https://www.worldometers.info/coronavirus/country/mac edonia/ , 2021.).

Healthcare workers (HCWs) face a substantially higher risk of infection and death due to excessive COVID-19 exposure (Shaukat et al., 2020). They are always on the frontline, whether it is an elective treatment, a medical emergency, or dealing with a pandemic like COVID-19. Moreover, the unpreparedness of the healthcare system and the novelty of the SARS-CoV-2 infection have made the HCWs a common and easy target for these infections (Ali et al., 2020). Much of the staff will be infected with the contagious disease, some will get very ill, and some will die. Early available evidence suggested that HCWs are being increasingly infected with the novel infection. In Italy, $20 \%$ of responding HCWs were infected (Lancet, 2020). In Spain, nearly $15 \%$ of all confirmed cases at the time of research were medical personnel (NPR, 2020). In the fight against the 2019 novel coronavirus (2019-nCoV), medical workers in Wuhan have been facing enormous pressure, including a high risk of infection and inadequate protection from contamination, overwork, frustration, discrimination, isolation, patients with negative emotions, a lack of contact with their families, and exhaustion (Lijun et al., 2020). Challenges for staff include not only the increased workload created by such outbreaks but also fears of contagion for themselves and their families, working with new and frequently changing protocols and personal protective equipment (PPE), caring for patients who are very sick and quickly deteriorating and caring for colleagues who have also fallen ill (Walton et al., 2020). The COVID-19 pandemic is having a profound effect on all aspects of society, including mental health and physical health (Holmes et al., 2020).

The ever-increasing number of confirmed and suspected cases, overwhelming workload, depletion of PPE, widespread media coverage, lack of specific drugs, and feelings of being inadequately supported may all contribute to the mental burden of these healthcare workers (Lai et al., 2020). The number of HCWs infected with COVID-19 in Spain is one of the highest in the world. A total of $56.6 \%$ of health workers present symptoms of post-traumatic stress disorder (PTSD), $58.6 \%$ anxiety disorder, $46 \%$ depressive disorder and $41.1 \%$ feel emotionally drained (Luceno, 2020). As COVID-19 continues to impact global society, HCWs are at risk for a number of negative well-being outcomes due to their role as care providers (Pearman et al., 2020). Protecting the mental health of these medical workers is thus important for control of the epidemic and their own long-term health. Previous experience from smaller scale epidemics and emerging literature around COVID-19 show that the unparalleled amount of stress that HCWs are dealing with, is associated with increased psychological morbidities (Tsamakis et al., 2020). Preliminary findings suggest adverse mental health effects in previously healthy people and especially in people with pre-existing mental health disorders (Moreno et al., 2020).

An acute stress reaction typically occurs after an unexpected life crisis (Patient, 2016). They include emotional, cognitive, physical and social reactions and will usually present in combination. Some people with long-term symptoms may need to be assessed to see if post-traumatic stress disorder (PTSD) is a possibility (Patient, 2017). It is important that medical staff are aware of these reactions and that it is normal to experience them, because distress arises from feeling guilt or shame about these reactions happening.

Health professionals must work in extreme conditions, in situations where resources can be scarce. For example, they must take care of a high number of patients in disaster or epidemic situations, often without sufficient beds or staff (Luceno et al., 2020). Moral injury is present when there is a betrayal of what is right, either by the self or by someone in legitimate authority, in a high stakes situation (Shay, 2014). Moral injury is now a looming reality for our front-line medical professionals, should they be forced to ration ventilators or other lifesaving resources (Senior, 2020). Research has shown that those staff who are quarantined experience guilt about leaving front lines understaffed, fear that they have contaminated their families and conflict about their roles as healthcare professionals and parents or careers (Walton et al., 2020). Staff who will be unable to work in clinical areas where they risk infection because of underlying health conditions or pregnancy or any other reason, may feel guilt. The pandemic and its consequences such as isolation requirements as well as uncertainty in diverse aspects of life burden the individuals with the stress that results in the increase of anxiety and depressiveness, which challenges the public mental health care systems (Sochańska, 2020). Psychological factors are important for understanding and managing societal problems associated with pandemics, such as the spreading of excessive fear, stigmatization, and xenophobia that occur when people are threatened with infection (Taylor, 2019).

Not all staff become distressed in the same way or to the same degree. Williams et al. (2014) note the ways in which people respond to emergencies and disasters. There are certain high-risk, vulnerable groups among medical responders, as well as certain risk factors for adverse psychological outcomes. Lack of social support and communication, maladaptive coping, and lack of training were important risk factors for developing negative psychological outcomes across all types of disasters (Naushad et al., 2019). 
Resilience is the individual's ability to deal with adversities as challenges, a process of positive adaptation to stress and adversity (Foster et al., 2019). Resilience is considered to be a powerful protective factor in buffering the detrimental impact of traumatic stress on the development of PTSD (Lee et al., 2014). The factors to cope with the current pandemic that have been identified are optimism, social support and bonding staying informed without overindulging in media consumption, ploying distraction strategies such as finding ways to have fun and laugh and reducing social isolation with online communication (Chen and Bonanno, 2020). In HCWs, a key factor for promoting resilience is to increase the sense of control over the adverse situation. The feeling of a lack of control and uncertainty at work may increase, leading to burnout. This syndrome is related to work. It is characterized by high emotional exhaustion, high levels of depersonalization and low personal accomplishment (Luceno, 2020).

As healthy HCWs are crucial in the aftermath of the outbreak, and in prevention of further outbreaks, losing a substantial part of the workforce to psychological or physical threats is detrimental. Therefore, the results can fuel healthcare organization policies and human resource practices to sustain the mental and physical health of HCWs during and after COVID-19 (Van Roekel et al., 2021). Whilst a pandemic is hard to control, there are best practices on how to help HCWs deal with the consequences through, for example, job redesign, counseling, a behavioral health hotline, stress management webinars, respite rooms and creating celebratory rituals (Wei et al., 2020). Resources have traditionally been put towards supporting staff once they have developed mental health pathology. Prevention is far more important than cure. Actions are needed to mitigate the impacts of COVID-19 on mental health by protecting and promoting the psychological wellbeing of HCWs during and after the outbreak. The package outlines the actions that team leaders can take to provide psychologically safe spaces for staff, together with guidance on communication and reducing social stigma, peer and family support, signposting others through psychological first aid, self-care strategies (e.g., rest, work breaks, sleep, shift work, fatigue, healthy lifestyle behavior), and managing emotions (e.g., moral injury, coping, guilt, grief, fear, anxiety, depression, preventing burnout and psychological trauma) (Blake et al., 2020). Drop-in sessions with psychologists/ psychiatrists have been recommended based on evidence from previous outbreaks. Colleagues and friends at work that can support each other will be an important part of maintaining good wellbeing during the pandemic (Walton et al., 2020).

Health care professionals are often self-reliant and many do not ask for help. Leaders must encourage team members to ask for help when they need it and emphasize that health care professionals and leaders need to rely on each other (Shanafelt et al., 2020). In addition, since HCWs often have a greater stigma against mental problems than the general public, it is worthwhile to address the needs of the HCWs during this pandemic and to provide appropriate psychological support for those people at high risk of mental problems (Zhu et al., 2020). Special interventions to promote mental well-being in HCWs exposed to COVID-19 need to be immediately implemented, with women, nurses, and frontline workers requiring particular attention (Wang et al, 2020).

"This pandemic is a marathon and not a sprint - take your breaks, try to keep leave and take time to 'reset' yourself" (Walton et al., 2020).

This paper aims to examine, by means of an anonymous survey, the attitudes and opinions of HCWs regarding the COVID-19 pandemic. In addition, it intends to screen their mental health condition as well as the sources and risks of developing psychological distress and other mental disabilities.

\section{Material and methods}

\section{Questionnaire - structuring process}

A questionnaire was prepared for the needs of this research. First, the construct that is to be assessed with the questionnaire as multidimensional was identified. A number of issues were considered before writing the questionnaire items and the format of its administration was determined. It was agreed that the respondents may be more likely to respond truthfully if they are allowed to complete the questionnaire on their own. The item format was determined as close ended (yes/no, multifactorial and Likert-type scales) to generate sufficient variance among the intended respondents. Before conducting a pilot test of the questionnaire on the intended respondents, the questionnaire items were tested on a small sample of respondents to screen for possible improvements. The questionnaire items were revised upon reviewing the results of the preliminary pilot testing and the final draft of the questionnaire was developed. Then, a pilot test was conducted among the intended respondents for initial validation. In this pilot test, the final version of the questionnaire was administered to a representative sample of respondents for whom the questionnaire was intended. This phase was conducted in the course of September and October 2020.

\section{Study design and data collection}

The research was conducted in a period December 2020 - January 2021, when the Macedonian healthcare system was still faced with a large number of patients and waiting for the vaccine. An anonymous survey was conducted on a voluntary basis. The survey included 82 HCWs (doctors, nurses/technicians, laboratory technicians and pharmacists) engaged in COVID-19 
Table 1. Descriptive presentation of the socio-demographic characteristics of the participants

\begin{tabular}{|c|c|c|c|}
\hline Characteristics of the participants' & & (f & $\%$ \\
\hline \multirow[b]{2}{*}{ Gender } & $\mathrm{M}$ & 26 & $31.7 \%$ \\
\hline & $\mathrm{F}$ & 56 & $68.3 \%$ \\
\hline \multirow{5}{*}{ Age } & $19-30$ & 22 & $26.8 \%$ \\
\hline & $31-40$ & 28 & $34.1 \%$ \\
\hline & $41-50$ & 22 & $26.8 \%$ \\
\hline & $51-60$ & 8 & $9.8 \%$ \\
\hline & $60+$ & & \\
\hline \multirow{3}{*}{ Degree } & Secondary vocational education & 30 & $36.6 \%$ \\
\hline & Associate's degree & 6 & $7.3 \%$ \\
\hline & Bachelor's degree & 46 & $56.1 \%$ \\
\hline \multirow{5}{*}{ Years of work experience } & $1-5$ & 12 & $14.6 \%$ \\
\hline & $6-10$ & 16 & $19.5 \%$ \\
\hline & $10-20$ & 28 & $34.1 \%$ \\
\hline & $21-30$ & 20 & $24.4 \%$ \\
\hline & $31+$ & 6 & $7.3 \%$ \\
\hline \multirow{6}{*}{ Who do you live with? } & Marriage / Partnership & 48 & $58.6 \%$ \\
\hline & With child / children & 6 & $7.3 \%$ \\
\hline & With parent / s & 4 & $4.9 \%$ \\
\hline & With extended family & 16 & $19.5 \%$ \\
\hline & Alone & 8 & $9.8 \%$ \\
\hline & Good & 54 & $65.9 \%$ \\
\hline \multirow{4}{*}{ What is your health condition? } & A chronic disease & 12 & $14.6 \%$ \\
\hline & More chronic diseases & 10 & $12.2 \%$ \\
\hline & Smoker & 26 & $31.7 \%$ \\
\hline & I consume alcohol occasionally & 28 & $34.1 \%$ \\
\hline
\end{tabular}

centers in the University Clinical Centre „Мајка Tereza“, Skopje, Republic of North Macedonia. 56 women and 26 men participated, mostly aged 31-40. Table 1 shows the socio-demographic data for the participants in the research.

The first part of the questionnaire, including 6 items, covers socio-demographic characteristics (gender, age, level of education, years of work experience and family and general conditions). The second part contains 9 questions about exposure to the disease, questions about the availability of psychological support, awareness questions about a COVID-19 infection and using PPE and questions related to risk assessment and personal protection. The third part of the survey consisting of 8 


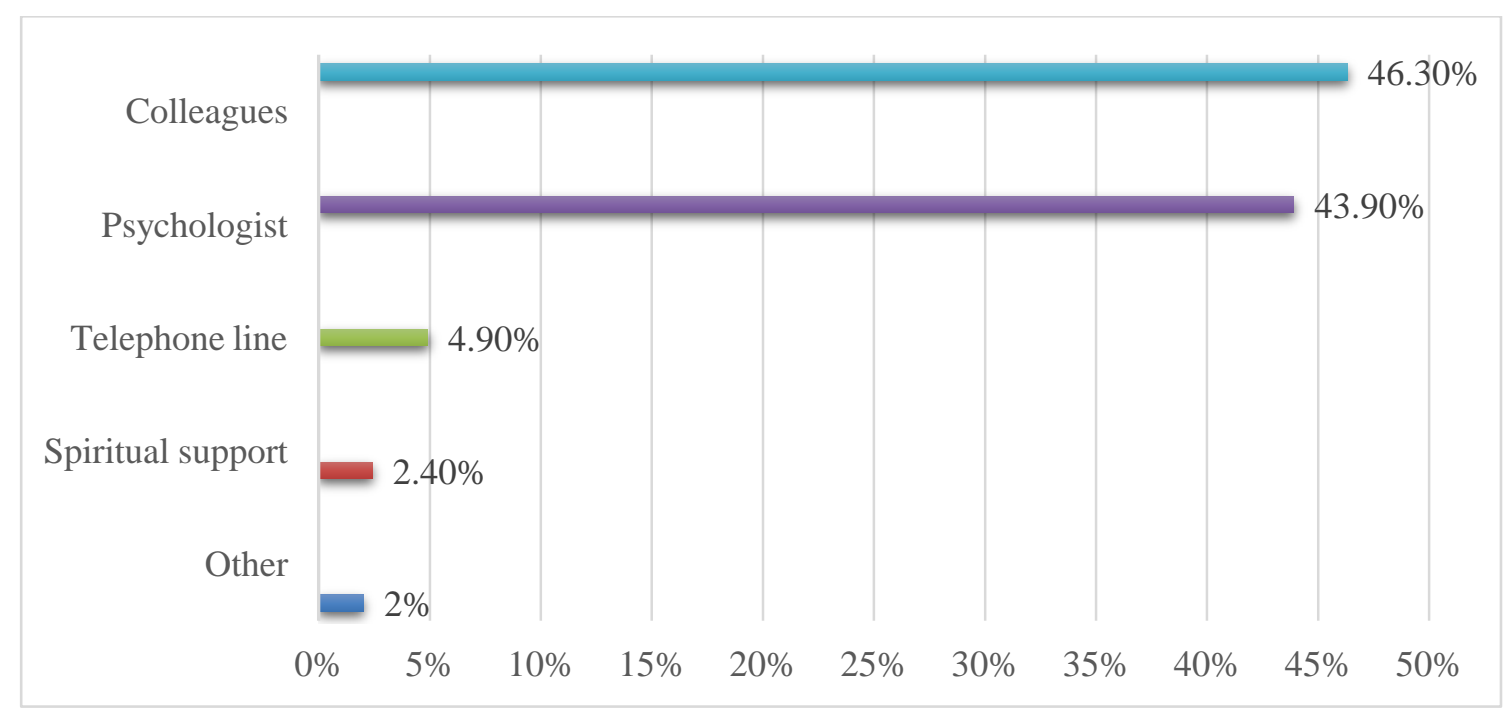

Fig. 1. Availability of different types of workplace support.

questions, pertains to an assessment of the degree of concern of the participants in relation to various factors. The average Cronbach's alpha value on the scale of concern $\alpha=0.78$. Finally, the survey included 9 questions for assessing the general condition of the participants during their engagement in the COVID-19 centers. The average Cronbach's alpha value on the scale of general condition $\alpha=0.73$.

In order to ensure that the content validation is adequately evaluated, we included experts from the University Clinic of Neurology, Skopje, which currently partially functions as a COVID-19 center.

A complete questionnaire is shown in Appendix 1.

The data collected were organized, tabulated and analyzed in SPSS statistical program. For statistical analysis descriptive methods, a method with mean value and standard deviation, Pearson correlation and confidence interval of $95 \%(p<0.05)$ were used.

Descriptive survey data, frequencies and percentages for individual responses are displayed. For multiple choice questions, the percentages were calculated so that the frequency of individual answers was divided by the total number of participants. For the third and the last part of the questionnaire we used the Likert psychometric scale survey, consisting of five statements, ranging from "I'm not worried at all" to "I am very worried" and five statements from "never" to "every time".

\section{Results}

When asked about the work they do, $73.2 \%$ of the participants answered that their work tasks include direct contact with people infected with the COVID-19 virus, while $26.8 \%$ did not have direct contact at their workplace. Furthermore, $82.9 \%$ of participants stated that during their work they were in contact with patients or colleagues who were later diagnosed with COVID-19, while $17.1 \%$ had no such contact. Most of the respondents (90.2\%) have not asked anyone for psychological support or help since the pandemic started and their work colleagues most often (46.3\%) support them. Fig. 1 shows the answers about the availability of different types of support.

$75.6 \%$ of the participants thought that they were sufficiently informed about the COVID-19 infection. Almost all participants received information about the infection (diagnosis, treatment, isolation measures, training for dressing/undressing of protective equipment) from several different sources, and the two most common sources of information were colleagues and official pages of the WHO and the Center for Disease Control and Prevention (CDCP). Fig. 2 shows the frequencies of participants' responses about the source of information regarding infection and treatment of suspected/positive COVID-19 patients.

Participants rated their personal risk of COVID-19 infection as high (43.9\%). Fig. 3 presents the opinion of health professionals regarding the level of personal risk from COVID-19 infection due to occupational exposure.

Almost half of the respondents consider that they are not sufficiently protected with personal protective equipment while working with patients suspected of/positive for COVID-19 (46.3\%). Despite working conditions and exposure, $85.4 \%$ of respondents said they had not considered relocating to another ward that did not work with suspected/positive for COVID-19 patients or resigning during a pandemic. The opinions about relocating to another ward or resignation and level of protection with PPE are shown in Fig. 4.

Regarding the level of concern, most of the HCWs are not worried at all that their physical health was 


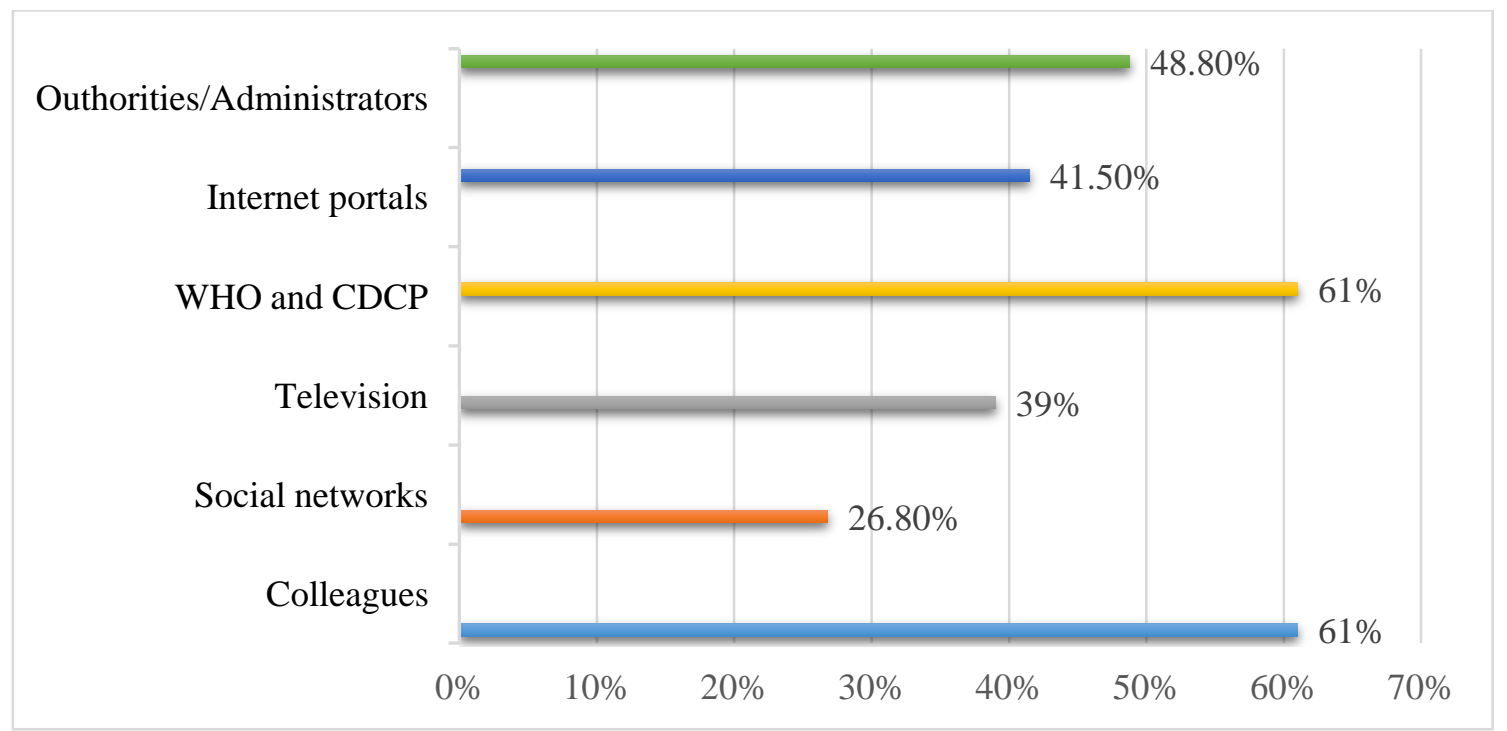

Fig. 2. Source of information and treatment of suspected/positive COVID-19 patients.

endangered, rarely worried about whether their PPE was appropriate and whether they use it adequately, occasionally worried about getting sick themselves or that their physical health was endangered, their family members/friends/neighbors will avoid them because of their work and about the availability of diagnostic tests, hospital beds/isolation units, specialized equipment and PPE. However, they are very worried that the infection will be passed on to members of their family, friends, negative patients, that they will have to go into selfisolation in their home and that this will affect their family and whether any of their colleagues will get sick and that there will not be enough staff available due to their illness or isolation. Table 2 shows the level of concern of HCWs during the COVID-19 pandemic.
The obtained results from the questions regarding the general condition of the participants during their engagement in the COVID-19 centers showed how often the HCWs were in a bad mental state. Most of the respondents never used sleeping pills or sedatives $(53.7 \%)$, rarely noticed that they are more forgetful $(36.6 \%)$ and reacted violently to ordinary situations $(41.5 \%)$ and sometimes thought they could no longer stand it $(26.8 \%)$. The participants were often mentally (29.3\%) and physically (34.1\%) exhausted, felt that they worked under great pressure $(26.8 \%)$ and had difficulty sleeping $(31.7 \%)$, but they had enough energy for family and friends every time $(29.3 \%)$. Table 3 fully shows the general condition of the participants during their engagement in the COVID centers.

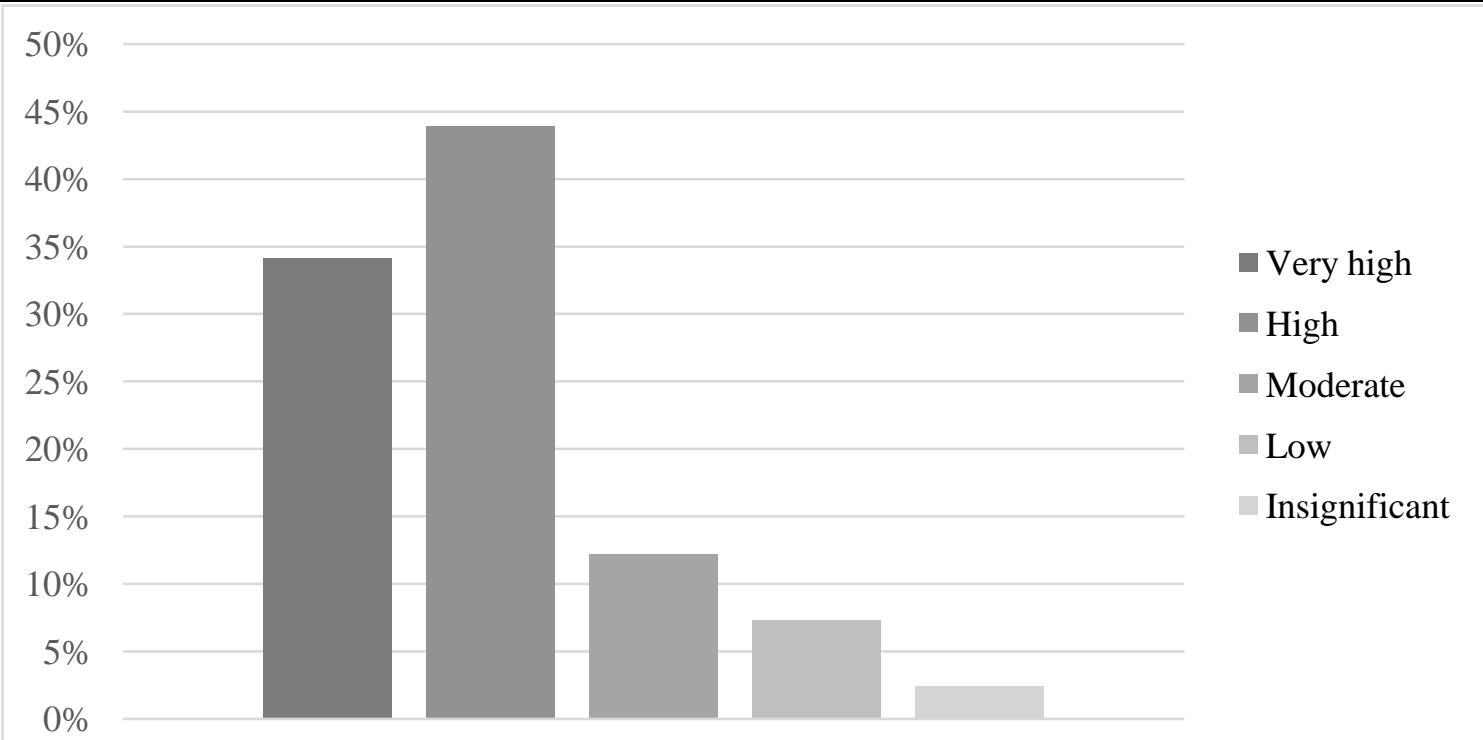

Fig. 3. Personal assessment of the risk of COVID-19 infection. 
Do you considered submitting a request for transfer to another ward does not wark with suspected/positive patients on COVID-19 or for resignation?

Do you think that you are sufficiently protected with PPE while working with patients?

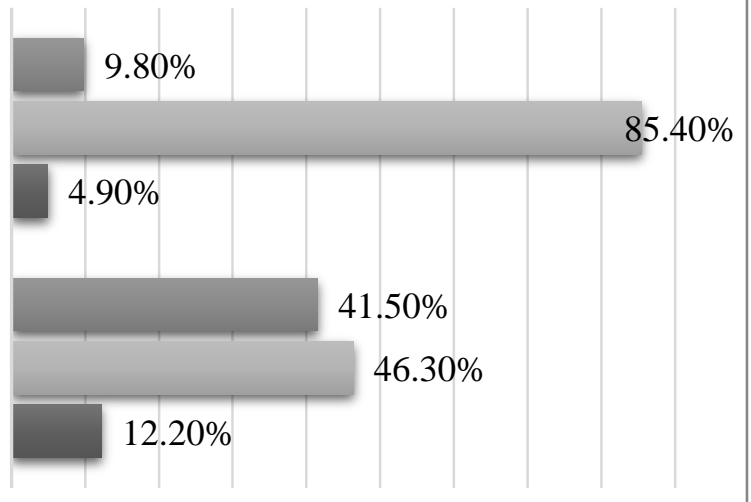

$0 \% 10 \% 20 \% 30 \% 40 \% 50 \% 60 \% 70 \% 80 \% 90 \%$

- Yes No $\quad$ I'm not sure

Fig. 4. The opinions about relocating to another ward or resignation and level of protection with PPE

The total result from the questions for assessing the general condition of the participants was calculated too. A higher result indicates a worse general condition of the participants during their engagement in the COVID-19 centers. The arithmetic mean of the variables was calculated and an average score of $2.9 \pm 1.3$ was obtained, which indicates that the participants in total experienced poor general conditions such as physical and mental exhaustion and high work pressure sometimes.

A statistically significant correlation was obtained between some variables. Participants whose work tasks included direct contact with COVID-19 patients were more concerned that their work put their family members and others at risk of infection and that some of their colleagues will get sick and that there will be not enough staff available due to their illness or isolation. The data are shown in Table 4.

\section{Discussion}

The results from the research showed that HCWs received a lot of information about working with suspected/positive COVID-19 patients from colleagues or official websites of the World Health Organization and the Center for Disease Control and Prevention, which indicates that health professionals were educated on their own initiative. Giving clear guidelines for the new schedule and work protocols indicates the existence of a clear plan and protection of workers from possible disease and transmission of the infection to other people. Knowing the employer's role and expectations clearly helps healthcare professionals stay focused on important and difficult work and thus, avoids uncertainty. Frequent changes of rules, unclear management criteria in a given situation, frequent changes in the workplace and time, among other difficulties at work create frustration, stress and anxiety. Most of the participants rate their risk of infection as high, which confirms the results of previous research suggesting that as many as $20 \%$ of COVID-19 patients are health professionals (Lancet, 2020).

Due to the intense general stress caused by the COVID-19 pandemic, a higher value of the indicators of stress, anxiety and depression was expected among the health workers engaged in the COVID-19 centers in the University Clinical Centre "Majka Tereza" Skopje. One of the possible explanations for these results is that health professionals who encounter stressful situations on a daily basis during their work (most of whom have 10-20 years of work experience) have developed resilience and good mechanisms for adjusting to change, coping with stress and unexpected events and difficulties as well as maintaining a positive attitude. In addition, the research was conducted at a time when the number of patients began to decline and the country was on the verge of vaccination.

The results regarding the situation in the work and family environment suggest that health professionals care more about colleagues and family members than about themselves, they are relatively confident in the proper use of protective equipment and are rarely concerned about its appropriateness. By comparing the risk assessment for self-infection and the concern that they will transmit the infection to their loved ones, colleagues and negative patients, health professionals demonstrate a humane component, great selflessness and care for others. Despite the constant stress and work under great pressure, they put the care of the patient before their own needs.

Because the number of participants living alone is small, no comparison can be made with the levels of stress in certain situations. Namely, contact with close people can have a positive effect on the level of stress experienced in different life situations. 
Table 2. Concerns of HCWs during the COVID-19 pandemic

\begin{tabular}{|c|c|c|c|c|c|}
\hline Cause for concern & $\begin{array}{l}\text { I am not } \\
\text { worried at all } \\
(\%)\end{array}$ & $\begin{array}{l}\text { I am rarely } \\
\text { worried } \\
(\%)\end{array}$ & $\begin{array}{c}\text { I am } \\
\text { occasionally } \\
\text { worried (\%) }\end{array}$ & $\begin{array}{c}\text { I am } \\
\text { moderately } \\
\text { worried }(\%)\end{array}$ & $\begin{array}{l}\text { I am very } \\
\text { worried } \\
(\%)\end{array}$ \\
\hline $\begin{array}{l}\text { If you get sick of COVID- } \\
19 \text { due to occupational } \\
\text { exposure and your } \\
\text { physical health are at stake }\end{array}$ & $17.1 \%$ & $9.8 \%$ & $29.3 \%$ & $22 \%$ & $22 \%$ \\
\hline Your mental health & 31.7 & 24.4 & 9.8 & 17.1 & 17.1 \\
\hline $\begin{array}{l}\text { Compliance with } \\
\text { protective equipment and } \\
\text { its use on the appropriate } \\
\text { way }\end{array}$ & $24.4 \%$ & $31.7 \%$ & $14.6 \%$ & $14.6 \%$ & $14.6 \%$ \\
\hline $\begin{array}{l}\text { One of your colleagues } \\
\text { will get sick and will not } \\
\text { have enough personnel due } \\
\text { to their illness or isolation }\end{array}$ & $19.5 \%$ & $14.6 \%$ & $17.1 \%$ & $19.5 \%$ & $29.3 \%$ \\
\hline $\begin{array}{l}\text { Availability of diagnostic } \\
\text { tests, hospital facilities, } \\
\text { specialized equipment for } \\
\text { the care of patients with } \\
\text { COVID-19 }\end{array}$ & $17.1 \%$ & $19.5 \%$ & $29.3 \%$ & $17.1 \%$ & $17.1 \%$ \\
\hline $\begin{array}{l}\text { The infection will be } \\
\text { passed onto members of } \\
\text { your family, friends, } \\
\text { negative patients }\end{array}$ & $7.3 \%$ & $4.9 \%$ & $17.1 \%$ & $22 \%$ & $48.8 \%$ \\
\hline $\begin{array}{l}\text { You will have to go into } \\
\text { self-isolation in your home } \\
\text { and this will affect your } \\
\text { family }\end{array}$ & $19.5 \%$ & $12.2 \%$ & $9.8 \%$ & $24.4 \%$ & $34.1 \%$ \\
\hline $\begin{array}{l}\text { Your family } \\
\text { members/friends/neighbors } \\
\text { avoid you because of your } \\
\text { work and it affects your } \\
\text { relationships }\end{array}$ & $22 \%$ & $17.1 \%$ & $26.8 \%$ & $22 \%$ & $12.2 \%$ \\
\hline
\end{tabular}

The participants were often mentally and physically exhausted, and felt that they worked under great pressure, which confirmed the fact that health care workers in the first line of defense against COVID-19 infection faced the burnout syndrome. However, they were not worried about their mental health.

Only a negligible number of participants in our study sought psychological help despite available psychologists and psychiatrists because one of the COVID-19 centers in which the examination was conducted is part of a neurological clinic. It is possible that health professionals in crisis situations do not expect psychological help in the workplace, but primarily seek it from colleges, family and friends. Such findings potentially imply the need for education on the importance of mental health care among health professionals and the destigmatization of seeking help from mental health professionals. As with physical illness, early detection of mental health problems enables more successful treatment and offers a better prognosis.

Sudden fluctuations in the professional role of health 
Table 3. General condition of the participants during their engagement in the COVID-19 centers

\begin{tabular}{lccccc}
\hline \multicolumn{1}{c}{$\begin{array}{c}\text { General } \\
\text { condition }\end{array}$} & $\begin{array}{c}\text { Never } \\
\%\end{array}$ & $\begin{array}{c}\text { Rare } \\
\%\end{array}$ & $\begin{array}{c}\text { Sometimes } \\
\%\end{array}$ & $\begin{array}{c}\text { Often } \\
\%\end{array}$ & $\begin{array}{c}\text { Every time } \\
\%\end{array}$ \\
\hline $\begin{array}{l}\text { How often are you mentally } \\
\text { exhausted? }\end{array}$ & $9.8 \%$ & $17.1 \%$ & $22 \%$ & $29.3 \%$ & $22 \%$ \\
$\begin{array}{l}\text { How often are you physically } \\
\text { exhausted? }\end{array}$ & $9.8 \%$ & $14.6 \%$ & $26.8 \%$ & $34.1 \%$ & $14.6 \%$ \\
$\begin{array}{l}\text { How often do you think you } \\
\text { can't take it anymore? }\end{array}$ & $22 \%$ & $22 \%$ & $26.8 \%$ & $19.5 \%$ & $9.8 \%$ \\
$\begin{array}{l}\text { Do you think that you work } \\
\text { under great pressure? }\end{array}$ & $22 \%$ & $12.2 \%$ & $19.5 \%$ & $26.8 \%$ & $19.5 \%$ \\
$\begin{array}{l}\text { Do you have enough energy } \\
\text { for family and friends? }\end{array}$ & $12.2 \%$ & $22 \%$ & $19.5 \%$ & $17.1 \%$ & $29.3 \%$ \\
$\begin{array}{l}\text { Do you have problems with } \\
\text { sleeping? }\end{array}$ & $14.6 \%$ & $17.1 \%$ & $22 \%$ & $31.7 \%$ & $14.6 \%$ \\
$\begin{array}{l}\text { Do you use sleeping or } \\
\text { calming pills? }\end{array}$ & $53.7 \%$ & $17.1 \%$ & $12.2 \%$ & $9.8 \%$ & $7.3 \%$ \\
$\begin{array}{l}\text { Do you notice that you are } \\
\text { more forgetful? }\end{array}$ & $14.6 \%$ & $36.6 \%$ & $29.3 \%$ & $12.2 \%$ & $7.3 \%$ \\
$\begin{array}{l}\text { Do you react violently to } \\
\text { ordinary situations? }\end{array}$ & $9.8 \%$ & $41.5 \%$ & $29.3 \%$ & $12.2 \%$ & $7.3 \%$ \\
\hline
\end{tabular}

Table 4. Correlation between variables

\begin{tabular}{lc}
\hline \hline & $\begin{array}{l}\text { Participants who at their workplace were } \\
\text { in contact with COVID-19 patients }\end{array}$ \\
\hline $\begin{array}{l}\text { Concern that the infection will be passed on to members of } \\
\text { their family, friends, negative patients }\end{array}$ & $-0.21^{*}$ \\
$\begin{array}{l}\text { Concern that some of their colleagues will get sick and that } \\
\text { will not have enough staff available }\end{array}$ & $-0.27^{*}$ \\
\hline$* p<0.05$ &
\end{tabular}

professionals in working with COVID-19 infection lead to new challenges and adjustments in the overall health sector. Author Wong states that conscientiousness is one of the strongest driving forces in the performance of work tasks. Increased education, training and preparation of health professionals for work in crisis situations are some of the effective measures to relieve mental stress for health professionals. Therefore, in crisis situations, it is important to strengthen the enthusiasm, knowledge and conscientiousness of health professionals (Wong et al., 2007). Insufficient education and readiness of health workers leads to insecurity of staff resulting in inadequate work. Knowledge of recent information is essential to ensure quality access and patient protection. If new knowledge is not acquired, feelings of dissatisfaction, threat and fear gradually arise, especially in crisis and stressful situations such as the COVID-19 pandemic (Bartels, 2005).

When interpreting the results, it is important to keep in mind that this is a relatively small, heterogeneous sample, which is also the main limitation of this research. The number of participants in individual groups is not equal and large enough. This prevents strong conclusions about possible intergroup differences. 


\section{Conclusion}

The COVID-19 pandemic is an exceptional challenge for both the entire population and health professionals. An unprecedented public health crisis caused by the SARS-CoV-2 virus has a major psychological impact on HCWs employed at COVID-19 centers and poses a major threat to their health and professional ability. The numerous difficulties that HCWs are exposed to on a daily basis weaken an individual's physical and mental resilience and thus affect competencies in working with COVID-19 patients. Maintaining the well-being of healthcare professionals and mental health in this time of crisis is essential.

Providing psychological support to $\mathrm{HCW}$ s is a crucial imperative for their further work and profession. Recognizing the sources of mental disabilities enables the development of targeted approaches for their support and addressing the challenges they face. The question is whether and to what extent acute symptoms of mental disorders will lead to chronic diseases such as post-traumatic stress disorder, chronic depression or anxiety. Fear of labeling, stigmatization and discrimination potentially prevents HCWs from seeking help. A set of measures is needed for fast and reliable early recognition of mental difficulties in health professionals, intervention and later rehabilitation.

The results of this research contribute to understanding the psychological health of HCWs during a pandemic, implying the need for education on the importance and care of mental health among health professionals and provide a basis for future more detailed studies.

\section{References}

Ali, S., Noreen, S., Farooq, I., Bugshan, A., Vohra, F., 2020. Risk Assessment of Healthcare Workers at the Frontline against COVID-19. Pak. J. Med. Sci. 36, S99-S103. Available at: https://doi.org/10.12669/pjms.36COVID19S4.2790.

Blake, H., Bermingham, F., Johnson, G., Tabner, A., 2020. Mitigating the Psychological Impact of COVID-19 on Healthcare Workers: A Digital Learning Package. Int. J. Environ. Res. Public Health 17(9), 2997. Available at: https://doi.org/10.3390/ijerph17092997.

Chen, S., Bonanno, G.A., 2020. Psychological adjustment during the global outbreak of COVID-19: A resilience perspective, Psychol. Trauma (S1), S51-S54. Available at: https://doi.org/10.1037/tra0000685.

Foster, K., Roche, M., Delgado C., Cuzzillo, C., Giandinoto, J.A., Furness, T., 2018. Resilience and mental health nursing: An integrative review of international literature. Int. J. Ment. Health Nurs. 28(1), 71-85. Available at: https://doi.org/10.1111/inm.1254.

Holmes, E.A., O'Connor, R.C., Perry, V.H., Tracey, I., Wessely, S., Arseneault, L., Ballard, C., Christensen, H., Silver, R.C., Everall, I., Ford, T., John, A., Kabir, T., King,
K., Madan, I., Michie, S., Przybylski, A.K., Shafran, R., Sweeney, A., Worthman, C.M., Yardley, L., Cowan, K., Cope, C., Hotopf, M., Bullmore, E., 2020. Multidisciplinary research priorities for the COVID-19 pandemic: a call for action for mental health science. Lancet Psychiatry 7(6), 547-560. Available at: https://doi.org/10.1016/S2215-0366(20)30168-1.

Lai, J., Ma, S., Wang, Y., Cai, Z., Hu, J., Wei, N., Wu, J., Du, H., Chen, T., Li, R., Tan, H., Kang, L., Yao, L., Huang, M., Wang, H., Wang, G., Liu, Z., Hu, S., 2020. Factors Associated With Mental Health Outcomes Among Health Care Workers Exposed to Coronavirus Disease 2019. JAMA Netw. Open 3(3), e203976. Available at: https://doi.org/10.1001/jamanetworkopen.2020.3976.

Lancet, 2020. COVID-19: protecting health-care workers. Available at: https://doi.org/10.1016/S0140-6736(20)30644-9 (last accessed: February 2021).

Lee, J.S., Ahn, Y.S., Jeong, K.S., Chae, J.H., Choi, K.S., 2014. Resilience buffers the impact of traumatic events on the development of PTSD symptoms in firefighters. J. Affect. Disord. 162, 128-133. Available at: https://doi.org/10.1016/j.jad.2014.02.031.

Lijun, K.L., Li, Y., Hu, S., Chen, M., Yang, C., Yang, B.X., Wang, Y., Hu, J., Lai, J., Ma, X., Chen, J., Guan, L., Wang, G., Ma, H., Liu, Z., 2020. The mental health of medical workers in Wuhan, China dealing with the 2019 novel coronavirus. Lancet Psychiatry 7(3), e14. Available at: https://doi.org/10.1016/S2215-0366(20)30047-X.

Luceno, L.M.., Velasco, B.T., Albuerne, Y.G., Garcia, J.M., 2020. Symptoms of Posttraumatic Stress, Anxiety, Depression, Levels of Resilience and Burnout in Spanish Health Personnel during the COVID-19 Pandemic. Int. J. Environ Res. Public Health 17(15), 5514. Available at: https://doi.org/10.3390/ijerph17155514.

Moreno, C., Wykes, T., Galderisi, S., Nordentoft, M., Crossley, N., Jones, N., Cannon, M., Correll, C.U., Byrne, L., Carr, S., Chen, E.Y.H., Gorwood, P., Johnson, S., Kärkkäinen, H., Krystal, J.H., Lee, J., Lieberman, J., Jaramillo, C.L., Männikkö, M., Phillips, M.R., Uchida, H., Vieta, E., Vita, A., Arango, C., 2020. How mental health care should change as a consequence of the COVID-19 pandemic. The Lancet Psychiatry 7(9), 813-824. Available at: https://doi.org/10.1016/S2215-0366(20)30307-2.

Naushad, V.A., Bierens, J.J., Nishan, K.P., Firjeeth, C.P., Mohammad, O.H., Maliyakkal, A.M., Hadan S.C., Schreiber, M.D., A Systematic Review of the Impact of Disaster on the Mental Health of Medical Responders, 2019. Prehosp. Disaster Med. 34(6), 632-643. Available at: https://doi.org/10.1017/S1049023X19004874.

NPR, 2020. Spain's Health Staff Are Catching The Coronavirus As Protective Gear Runs Short. Available at: https://www.npr.org/sections/coronavirus-liveupdates/2020/03/31/824654965/spains-health-staff-arecatching-the-coronavirus-as-protective-gear-runs-short (last accessed: February 2021).

Patient, 2016. Acute Stress Reaction. Available at: https://patient.info/mental-health/stress-management/ acute-stress-reaction (last accessed: February 2021).

Patient, 2017. Post-traumatic stress disorder. Available at: https://patient.info/mental-health/post-traumatic-stressdisorder-leaflet (last accessed: February 2021).

Pearman, A., Hughes, M.L., Smith, E.L., Neupert, S.D., 2020. 
Mental Health Challenges of United States Healthcare Professionals During COVID-19, Front Psychol, 11, 2065. Available at: https://doi.org/10.3389/fpsyg.2020.02065.

Senior, J., 2020. Opinion/The Psychological Trauma That Awaits Our Doctors and Nurses. The New York Times. Available at:

https://www.nytimes.com/2020/03/29/opinion/coronavirusventilators-rationing-

triage.html?referringSource=articleShare

(last accessed: February 2021).

Shanafelt, T., Ripp, J., Trockel, M., 2020. Understanding and Addressing Sources of Anxiety Among Health Care Professionals During the COVID-19 Pandemic. JAMA 323(21), 2133-2134. Available at: https://doi.org/10.1001/jama.2020.5893.

Shaukat, N., Ali, D.M., Razzak, J., 2020. Physical and mental health impacts of COVID-19 on healthcare workers: a scoping review. Int. J. Emerg. Med. 13(1), 40. Available at: https://doi.org/10.1186/s12245-020-00299-5.

Shay, J., 2014. Moral injury. Psychoanalytic Psychology 31(2), 182-191. Available at: https://doi.org/10.1037/a0036090.

Sochańska, M.F., 2020. Mental health in the pandemic times. Society Register 4(3), 67-78. Available at: https://doi.org/10.14746/sr.2020.4.3.03.

Taylor, S., 2019. The Psychology of Pandemics: Preparing for the Next Global Outbreak of Infectious Disease; Cambridge Scholars Publishing: Newcastle upon Tyne, UK, 2019.

Tsamakis, K., Rizos, E., Manolis, A.J., Chaidou, S., Kympouropoulos, S., Spartalis, E., Spandidos, D.A., Tsiptsios, D.,Triantafyllis, A.S., 2020. COVID-19 pandemic and its impact on mental health of healthcare professionals. Exp. Ther. Med. 19(6), 3451-3453. Available at: https://doi.org/10.3892/etm.2020.8646.

Van Roekel, H., Van der Fels, I.M.J., Arnold, B., Bakker, A.B., Tummers, L.G., 2021. Healthcare Workers Who Work With COVID-19 Patients Are More Physically Exhausted and Have More Sleep Problems. Front Psychol. 2021. Available at: https://doi.org/10.3389/fpsyg.2020.625626.

Walton, M., Murray, E., Christian, M.D., 2020. Mental health care for medical staff and affiliated healthcare workers during the COVID-19 pandemic. Eur. Heart J. Acute Cardiovasc. Care 9(3), 241-247. Available at: https://doi.org/10.1177/204887262092279.

Wang, C., Horby, P.W., Hayden, F.G., Gao, G.F., 2020. Novel coronavirus outbreak of global health concern. Lancet 395(10223), 467-536. Available at: http://dx.doi.org/10.1016/S0140-6736(20)30185-9.

Wei, E., Segall, J., Villanueva, Y., Dang, L. B., Gasca, V. I., Gonzalez, M. P., Roman, M., Justiniano, I.M., Cohen, A.G., Cho, H.J., 2020. Coping with Trauma, celebrating life: reinventing patient and staff support during the COVID-19 pandemic. Health Aff. (Millwood) 39(9), 15971600. Available at: https://doi.org/10.1377/hlthaff.2020.00929.

WHO, 2021. Coronavirus Disease (COVID-19) Dashboard. Available at: https://covid19.who.int/ (last accessed: February 2021).

WHO, 2020. Virtual press conference on COVID-19 - 11 March 2020. Available at: https://www.who.int/docs/defaultsource/coronaviruse/transcripts/who-audio-emergenciescoronavirus-press-conference-full-and-final11 mar2020.pdf?sfvrsn=cb432bb3_2 (last accessed: February 2021).

Williams, R., Bisson, J., Kemp, V., 2014. Principles for responding to people's psychosocial and mental health needs after disasters. Royal College of Psychiatrists 2014. Available at: https://www.apothecaries.org/wpcontent/uploads/2019/02/OP94.pdf

Zhu, Z., Xu, S., Wang, H., Liu, Z., Wu, J., Li, G., Miao, G., Zhang, C., Yang, Y., Sun, W., Zhu, S., Fan, Y., Chen, Y., Hu, J., Liu, J., Wang, W., 2020. COVID-19 in Wuhan: Sociodemographic characteristics and hospital support measures associated with the immediate psychological impact on healthcare workers. Eclinical Medicine 24, 100443. Available at: https://doi.org/10.1016/j.eclinm.2020.10044. https://www.worldometers.info/coronavirus/country/maced onia/ (last accessed: February 2021). 


\title{
Влијание на различни фактори поврзани со COVID-19 пандемијата врз менталното здравје на здравствените работници во Република Северна Македонија
}

\author{
Сања Филкова ${ }^{1 *}$, Бранка Пашалиска Цветков ${ }^{2}$, Васко Алексовски $^{2}$, \\ Оливера Крстиќ Наковска ${ }^{3}$, Димитар Каркински ${ }^{3}$, \\ Ирина Анѓеловска ${ }^{3}$, Анѓела Дебрешлиовска ${ }^{3}$ \\ ${ }^{1}$ Институт ${ }^{1}$ Јавна установа од областа на здравството за потребите на \\ Универзитетски Клиники, Завод и Ургентен иентар, Сектор Аптека, \\ Мајка Тереза 17, 1000 Скопје, Република Северна Македонија \\ ${ }^{2}$ Универзитетска Клиника за Неврологија, Мајка Тереза 17, \\ 1000 Скопје, Република Северна Македонија \\ ${ }^{2}$ Универзитетска Клиника за Пулмологија и Алергологија, \\ Мајка Тереза 17, 1000 Скопје, Република Северна Македонија
}

Клучни зборови: COVID-19, здравствени работници, ризици, мерки, ментално здравје

Од декември 2019. година светот се соочува со досега невидена инфекција предизвикана од новиот сој на коронавирус наречен SARS-CoV-2. Пандемијата на COVID-19, покрај тоа што влијае на секој аспект од секојдневниот живот, дополнително влијае на веќе високото ниво на стрес, анксиозност и депресија со кои се соочуваат здравствените работници на глобално ниво. Заштитата на менталното здравје на здравствените работници треба да биде препознена како императив за време на пандемијата.

Целта на овој труд беше да ги испита ставовите и мислењата на здравствените работници за пандемијата, состојбата на нивното менталното здравје како и изворите за ментални попречености, по пат на анонимна анкета. Истражувањето опфати здравствени работници (лекари, сестри/техничари и фармацевти) ангажирани во COVID19 центри во Универзитетски Клинички Центар „Мајка Тереза“, Скопје. Резултатите од спроведеното истражување укажуваат дека здравствените работници за време на ангажираноста во COVID-19 центрите се соочувале со синдромот на согорување, страв од инфицирање, пред се на членовите на семејството, колегите или негативните пациенти, изолација и др. Најголем број од учесниците никогаш не побарале психолошка помош, повремено помислувале дека повеќе не можат да издржат и често имале повеќе потешкотии со спиењето, но не користеле таблети за спиење или смирување. Речиси половина од учесниците сметале дека не се соодветно заштитени на работното место. Негативните последици на психичкото здравје повеќе се изразени кај здравствените работници кои се директно ангажирани во лекувањето на болните од COVID-19.

Ова истражување придонесува за подобро разбирање на психичкото здравје на здравствените работници и потребите за интервенции од страна на системот во вид на едукација и заштита. 
Appendix 1.

\section{THE QUESTIONNAIRE IS ANONYMOUS}

I

1. Gender:

- Female

- Male

2. Age:

- $19-30$

- $\quad 31-40$

- $41-50$

- $51-60$

- $60+$

3. Degree:

- Secondary vocational education

- Associate's degree

- Bachelor's degree

4. Years of work experience

- 1-5

- 6-10

- $10-20$

- $21-30$

- $31+$

5. Who do you live with?

- Marriage / Partnership

- Marriage / Partnership with child / children

- Marriage / Partnership

- With parent/s

- With extended family

- Alone

6. What is your health condition? (multiple answers are possible)

- Good

- A chronic disease

- More chronic diseases

- Smoker

- I consume alcohol occasionally

II

1. Were you in direct contact with suspected / positive on COVID-19 patients at your workplace?

- Yes

- $\quad$ No

2. Were you in contact with patients / colleagues at your workplace who were diagnosed with the disease COVID-19 later?

- $\quad$ Yes

- No

3. Have you asked anyone for psychological support and help since the pandemic started in your workplace?

- No

- If yes, to whom? 
4. At your workplace, which of the following are available for psychological support and help:

- Colleagues

- Psychologist

- Telephone line for psychological support and help

- Spiritual support

- $\quad$ Other

5. Do you think you are sufficiently informed about COVID-19 infection, working with patients suspected / positive on COVID-19 and using PPE?

- $\quad$ Yes

- No

- I'm not sure

6. You have received information for infection and treatment of suspected / positive COVID-19 patients from: (multiple answers are possible)

- $\quad$ Authorities / Administrators

- Internet portals

- Official websites of the World Health Organization and the Center for Disease Control and Prevention

- Television

- Social networks

- Colleagues

7. How will you assess your risk of contracting COVID-19 infection?

- Very high

- High

- Moderate

- Low

- Insignificant

8. Do you think you are sufficiently protected with PPE while working with patients?

- Yes

- $\quad$ No

- I'm not sure

9. Have you considered submitting a request for transfer to another ward that does not work with suspected / positive patients on COVID-19 or for resignation?

- Yes

- No

- I'm still thinking

\section{QUESTIONS ABOUT YOUR CONCERNS}

1.If you get sick of COVID-19 due to occupational exposure and your physical health are at stake

- I'm not worried at all

- I'm rarely worried

- I'm occasionally worried

- I'm moderately worried

- I'm very worried

2. Your mental health

- I'm not worried at all

- I'm rarely worried

- I'm occasionally worried

- I'm moderately worried

- I'm very worried 
3. Compliance with personal protective equipment and its use on appropriate way

- I'm not worried at all

- I'm rarely worried

- I'm occasionally worried

- I'm moderately worried

- I'm very worried

4. One of your colleagues will get sick and will not have enough personnel due to their illness or isolation

- I'm not worried at all

- I'm rarely worried

- I'm occasionally worried

- I'm moderately worried

- I'm very worried

5. Availability of diagnostic tests, hospital facilities, specialized equipment for the care of patients with COVID-19

- I'm not worried at all

- I'm rarely worried

- I'm occasionally worried

- I'm moderately worried

- I'm very worried

6.The infection will be passed onto members of your family, friends, negative patients

- I'm not worried at all

- I'm rarely worried

- I'm occasionally worried

- I'm moderately worried

- I'm very worried

7. You will have to go into self-isolation in your home and this will affect your family

- I'm not worried at all

- I'm rarely worried

- I'm occasionally worried

- I'm moderately worried

- I'm very worried

8. Your family members / friends / neighbors avoid you because of your work and it affects your relationships

- I'm not worried at all

- I'm rarely worried

- I'm occasionally worried

- I'm moderately worried

- I'm very worried

\section{QUESTIONS ABOUT YOUR GENERAL CONDITION}

1.How often are you mentally exhausted?

- Never

- Rare

- Sometimes

- Often

- Every time

2. How often are you physically exhausted?

- Never

- Rare

- Sometimes

- Often

- Every time 
3. How often do you think you can't take it anymore?

- Never

- Rare

- Sometimes

- Often

- $\quad$ Every time

4. Do you think that you work under great pressure?

- Never

- Rare

- Sometimes

- Often

- $\quad$ Every time

5. Do you have enough energy for family and friends?

- Never

- Rare

- Sometimes

- Often

- Every time

6. Do you have problems with sleeping?

- Never

- Rare

- Sometimes

- Often

- Every time

7. Do you use sleeping or calming pills?

- Never

- Rare

- Sometimes

- Often

- $\quad$ Every time

8. Do you notice that you are more forgetful?

- Never

- Rare

- Sometimes

- Often

- $\quad$ Every time

9. Do you react violently to ordinary situations?

- Never

- Rare

- Sometimes

- Often

- Every time 